\title{
The Meaning of Tulembang and Tupakbiring Mantras in the Life of Makassar Ethnic
}

Muhammad Syafri Badaruddin *

\begin{tabular}{l} 
Article history: \\
\hline Received March $1^{\text {st }}, 2016$ \\
Revised March $30^{\text {th }}, 2016$ \\
Approved April $15^{\text {th }}, 2016$ \\
\hline Keyword: \\
Text structure, \\
Text function, \\
The meaning of text, \\
Inheritance strategy, \\
Mantra.
\end{tabular}

Author Correspondence: First author,

Hasanuddin University Makassar, Indonesia

Email: esfribad@yahoo.co.id

\begin{abstract}
Mantra was the oldest form of literature in Indonesia as an aspect of old culture which still survives and was used by traditional communities until now. Makassar traditional societies use mantra according to their needs. Mantra for planting rice or mantra for cultivation is called Tulembang, while mantra for fishing was called Tupakbiring. The mantra was in the form of expressions or words and could bring magic power. The power aims to provide strength for human in performing various activities. The forms could be praises to something to be considered as sacred such as gods, spirits, animals, or God usually uttered by sanro (shaman) and pinati (diviner).The meaning of mantra text contains recognition, hope, sanctity of self and heart, serenity, and inner satisfaction. The inheritance strategies were vertical and horizontal
\end{abstract}

Copyright $@ 2016$ International Journal of College and University. All rights reserved.

Article cited by | DOI |Orcid | OAI DOAJ | Thomson Reuters | Scopus |

\section{Introduction}

The significance of study on mantra in the traditional literature is based on the existing link between mantra and society. The community creates mantra. It cannot exist if there is no heir society. Similarly, the traditional societies that cling to the customs can not be separated from the life of mantra. Beliefs in supernatural power always encourage them to realize that power into concrete manifestation to meet their needs.In the life of traditional society of Makassar, mantra is used in a variety of customs, i.e during the rice planting ritual (Tulembang mantra) and ritual of fishing season (Tupakbiring mantra). The two kinds of mantras cannot be separated from the community within asociety, the community living in the plains and those living in coastal areas. People who live in mountainous areas are called Tulembang or Turaya while people who live on the beach are called Tupakbiring (Maknun, 2006; 1-2). It is then formed two types of mantra in Makassar community.

Tulembang and Tupakbiring mantras need to be preserved and the noble values of local culture need to be uncovered to enrich the cultural heritage. Tupakbiring and Tulembang mantras contain elements of language, literature, culture, and the life of Makassar people who are religious and philosophical. Therefore, inventory and documentation of the mantras should be done from various areas in South Sulawesi in particular and Indonesia in general.

Tulembang and Tupakbiring mantras can be used as literary texts, because they use language as a medium and have a system of signs that have meaning. Ratna (2006: 97) says that by means of signs, the process of human life becomes more efficient. With the mediation of signs, people can communicate with each other, even with other beings outside himself. Therefore, mantras of Tulembang and Tupakbiring as one kind of long poems are interesting to study from the aspects of semiotics.

Tulembang and Tupakbiring mantras are chosen as the research object because those mantras are still used by farmers in the area Bukrung-bukrung, District of Pattalassang, Gowa. Tupakbiring mantra is also still

\footnotetext{
*Hasanuddin University Makassar, Indonesia: esfribad@yahoo.co.id
} 
used in the area of Pallaklakang, District of North Galesong, Takalar. Fourteen mantras in both villages are taken into consideration based on the function and the intensity of the use of mantras in in the life of Makassar community.

In addition, the reason for choosing Tulembang and Tupabbiring mantras is due to the fact that in spite of the majority of Makassar people are Moslem but they still use mantras. This suggests that mantra does not only have a uniqueness and richness in the use of archaic words that are rarely used in everyday conversation, but the meaning of words in the mantra represent things that exist in the lives of Makassar people. In addition, each mantra of Tulembang and Tupakbiring contains natural and supernatural things, customs and cultural aspects. The research indicates the importance of documenting cultural treasures through mantras used by Makassar community.

Semiotics is a science of signs that studies sociocultural phenomena including literature as a system of signs (Preminger, 1974: 980). Signs have two aspects, namely: the signifier and signified. Signifiers are the formalform of sign, in the form of units of sounds or letters in written literature, while the signified is characterized by the signifier.Based on the relationship between signifier and signified and the sign, there are three types of signs, namely: icons, indexes and symbols. Icon is a sign that the signifier and signified indicate to have anatural relationship, which is the signifier is the same as the signified, such as a picture of house on a map showing that the house is signified and marks a real home.

Index is a sign inwhich the signifier and signified show a natural affinity that is causality, such as a smoke marks out fire, cloud overcast rain. Symbols are signs that did not signify any natural affinity, arbitrary relation by convention. Most of language sign are in the form of symbols. In addition to the three signs there is a sign of the so-called symptoms that the signifiedis uncertain. For example, the high body temperature does not indicate a specific disease (Culler, 1981: 40).

As regard to the signification of the mantras of traditional Makassar community, Riffaterre (1978: 2-3) semiotically argues that in poetry, indirectness of expression has the main position. Inndirectness of expression is an expression of thoughts or ideas expressed indirectly. The indirectness is caused by the presence of displacing of meaning, distorting of meaning, and creating of meaning. Riffaterre (1978) states that the replacement of sense is caused by the use of metaphor and metonymy, as well as other figurative language. Irregularities of meaning are caused by three things: ambiguity, contradiction and nonsense. Creating of meaning is through enjambement, homologue, and typography.

In this study, the reading of the text's meaning of mantra is done heuristically and hermeneutically in order to find coherent and intact units of meaning. Related to the analysis of the previous function, the meaning of the text of Tulembang and Tupakbiring mantras is examined using theological, social, and cultural meanings

The signification in Tulembang and Tupakbiring mantras is a word or phrase that can bring magical power, spells and charms that can contain the power and granted wishes according to the owner intentions. It can be seen from the choice of words and the use of symbols of various things that are considered sacred (prophets, companions of the prophet, the angels and the forces of nature). This kind of signification is considered as part of expressing intention inthe form of indirectness of meaning.

\section{Research Method}

In order to assess mantras of Tulembang and Tupakbiring, this study used a qualitative research design. According to Semi (1993: 23) a qualitative study does not use figures but put internalization before the interaction between concepts being studied empirically. Moleong (2000: 6) says that the qualitative study indicates that the collected data are in the form of words, images and not numbers.

Viewed from the nature of the research that discusses the culture of an area, the research is required to obtain data and assess the social problems of local society. Therefore, this study is included in field work research. The research starts from the acquisition of the texts. The texts were obtained by recordingofthe informant reading mantrasand then transcribed in accordance with the voice recordings. Text transcripts were then translated into Indonesian. For the sake of analysis, Tulembang and Tupakbiring mantras were amended and its translation are adapted. Furthermore, field research was conducted to obtain data of Tupakbiring and Tulembang mantras.

The research also made used of library study in the form of research reports or other articles that are relevant to the issues being investigated as a source of secondary materials. In addition, information was also taken from electronic media through the internet, for example the articles, electronic books, and research results.

The method used is descriptive analysis, describing aspects of literature contained in Tulembang and Tupakbiring mantras. Both mantras are analyzed by means of a semiotic interpretation. For example, the meaning contained, resulting from heuristic and hermeneutic readings unveil the model found in Tulembang and Tupakbiring mantras. 
In relation to the signification of Tulembang and Tupakbiring mantras, it is the duty of reader or researcher to give the meaning of a literary work. Particularly in the signification of a poem, the process begins with the heuristic reading, namely the first level of reading to understand the meaning linguistically. It is then followed by capturing the sense of the existing text and interpreting it with the appropriate language. Readers should have the linguistic competence in order to capture the meaning and elements according to language skills based on the function of language as a means of communication to present the outside world (mimetic function).Then, the reader should upgrade it to a second level that is hermeneutic reading to interpret the meaning intact. Readers should understand what they have read and modify their understanding of it. Inside there are codes of literary works tobe revealed (decoding) on the basis of its significance. To that end, the sign in poetry has a meaning after reading and signification to it. Riffaterre also revealed the method of poem signification meaning semiotically. Accordingly, Riffaterre theory is right to describe mantras of Tulembang and Tupakbiring, as one kind of poetry. Steps of poem signification presented by Riffaterre give space to reveal the meaning contained in Tulembang and Tupakbiring mantras totally.

\section{Results and Analysis}

Signification in Tulembang and Tupakbiring mantras is a word or phrase that can bring magical power, spells and charms that can contain the power and grant according to the owner intentions. It can be seen from the choice of words and the use of various symbols that are considered sacred (prophets, companions of the prophet, the angels and the forces of nature). This kind of signification is considered as part of expressing intention inthe form of meaning indirectness.

\subsection{The meaning of Tulembang mantra text}

The text of Tulembang mantra was interpreted theologically and became the foundation for traditional farming communities of Makassar ethnic, in accordance with the faith of the owner community. Theologically, Tulembang mantra is able to give inner calmness and strength of belief as a divinity of the owner society.

(1) Mantra of selecting seeds (Akbine)

Bismillahirrahmanirrahim

Tallasak kulamung

Tallasak kulamungang

Tallasak nilamungi

Sikontu ummakna nabbita

Anak cucunna Adam

I raya - I lau

I timboro - I wara

Battu ngaseng mako mae

Angkatekneangi

Angkarannuangi

Sabak Allah Taalah siagang nabbi Muhammad

Bismillahirrahmanirrahim

'I sowed seeds of life'

'seeds of life I showed'

'life seedlings I showed'

'All the deciples of Prophet Muhammad'

'the descendants of prophet Adam'

'in the East - in the West'

'in the South - in the North'

'Please come to the fields'

'beatify'

'please'

'Because Allah with Prophet Muhammad'

Barakka Lailah Illallah

BarakkaAnnaMuhammadarrasulullah

Theological meaning of Akbine mantrais seen in the opening sentence, namely Bismillahirrahmanirrahim. Bismillahirrahmanirrahim means 'by uttering the name of Allah, the Most Gracious, Most Merciful. The traditional farmers of Makassar society say Bismillahirrahmanirrahim before doing an activity. The line Bismillahirrahmanirrahim derived from Arabian. The word is the creation of a 
meaningful index that gain or get something desired because of God. It means that hope is an index to the belief in the power of Allah.

Denotatively, the lines above indicate, that Allah is believed to be Compassionate, the Merciful. Connotatively, these lines showed high expectations of the addressor, so as to bring the magic of the mantra. Other evidence theologically is the name of the Prophet Muhammad. The use of the name shows the meaning of addressor's faith. Theologically, Allah is believed to bring blessing and the Prophet Muhammad as an intermediary that can bring God's intercessory because it is believed that Sabak Taalah siagang nabbi Muhammad 'Allah with Prophet Muhammad'. The Prophet Muhammad is believed to be the Apostle of God to convey the teachings of Islam to mankind.

Theological meaning of Akbine mantra is seen in the use of the word Adam. It is understood that the beginning of the process (selecting seeds) and the end (harvest) should be done with seriousness and rigor. If that is done, it will provide happiness and pleasure. In other words, this mantra is considered as a mediation of request that the process of sowing the seeds are given a perfect result, so that the next harvest bring about happiness due to good results

(2) Mantra to start sowing rice paddy (Pamula Annanang Ase)

Yukkung, yakkung, yaccing

Kupasicinik mako anne yaccing

Anrong tumallasukkannu

Mangge tumappajarinu

Nakammiko patampulo malaekak

Sicinikki ritallung bulanga

Barakka Lailaha Illallah

Barakka Anna Muhammadarrasulullah

'You, me, paddy'

'I take you paddy to meet'

'mother who gave birth'

'father who made you'

'you are guarded by forty angels

'see you the following three months'

Barakka Lailaha Illallah

Barakka Anna Muhammadarrasullullah

Theological meaning of Pammula Annanang Asesama mantra with Aklessoro Ase and Appasuki Pakjeko mantras, is seen in the closing sentence Barakka Lailaha Illallah. Denotatively, the sentence shows the oneness of Allah that there is no God but Allah. Connotatively, the sentence indicates the recognition of theaddressor. In searching for sustenance we must have a clean heart and acknowledge that there is no god but Allah and Allah is the only Substance that is worthy of worship and able to provide sustenance. The word Barakkais a hope of blessing and Lailaha Illallah show the recognition of the owner community.

Another thing defined is the use of the word yakkung ' $\mathrm{I}$ '. The word is the kind of nonsense word, while the connotation of the word yukkung is that it can be interpreted as God. This is confirmed in the sentence Kupasicinik mako anne yaccing 'I bring you rice'. The meaning 'to unite' in the sentence is understood that God is the owner of sustenance and only God can give sustenance and prosperity. With that meaning, traditional farmers of Makassar believe that it is important to approach the Lord so that all the wishes come true.

The sentence Anrong tumallasukkan nu / Mangge tumappajarinu 'the mother who had you / father who made you', is expected that by uttering the name of father and mother as the parents of origin of any human seed is a reference to the process of planting a seed that is considered to be like the process of human birth. This mantra contains many iconity. The word anrong 'mother', mangge 'father', Yukkung, yakkung, yaccing become iconic signs that reinforce the meaning of this mantra. The word 'mother' means birth, the word 'father' means 'planting', Yukkungis interpreted as speakers or living executor, yakkung is interpreted as God or giver of sustenance and livelihood, yaccing is interpreted as rice or source of life.

The iconic words are interrelated with each other. Those words reflect the intent and purposeof this mantra, the pleading or the expectation that at the beginning of the rice planting they have been given a blessing and safety, as well as abundant sustenance.

Theological meaning of Pammula Annanang Ase mantra is seen in the use of the phrase Nakammiko patampulo malaekak 'you are guarded by forty angels'. This mantra has a theological meaning because interpret angel as a guardian. Angel is a symbol of holy beings created by God to meet the needs of humans 
and other creatures. That is to say, this sentence is interpreted as an expectation of protection from something that is purified.

(3) Mantra of Planting Rice Paddy (Annanang Ase)

Oh yaccingku nakutanangko rijekne

Kupatimboko ributta

Bintoeng palliserannu

Bulang papa kaciknongnu

Alloa pangnyappuruknu

Nairik-irikko anging

Anging battu ri Makka

Nakarenai anging battu ri Madinah

Ritallung bulang kisicinik

Barakka Lailaha Illallah

Barakka Anna Muhammadarrasulullah

'Oh my rice, I sow You in the water'

'I grow You on the land'

'the stars are the content of your paddy'

'the moon is your clarity'

'the sun shines on you'

'the breeze rock you'

'the wind from Mecca'

'Mocked by the wind from Madina'

'three months to come we meet'

Barakka Lailaha Illallah

Barakka Anna Muhammadarrasulullah

Theological meanings of Annanang Ase mantra is the same as Pammula Annanang Ase, Aklessoro Ase, and Appasuki Pakjeko mantras, bearing the closing line Barakka Lailaha Illallah. Denotatively, the line indicates the oneness of Allah, that there is no God but Allah. Connotatively, the line indicates the addressor recognition. In searching for sustenance we must have a clean heart and acknowledge that there is no God but Allah and Allah is the only substance that is worthy of worship and able to provide sustenance. The word Barakka is the hope of blessing and Lailaha Illallah shows the recognition for the owner community.

Another thing that can be interpreted is inner peace since this mantra is a prayer to God and will bring inner satisfaction for the addressor and addressee. It is seen in the phrase Ritallung bulang kisicinik 'three months to come we meet '. That phrase suggests the belief that planted rice be grownand kept byAllah well, so confidently the rice can be harvested three months to come with a good result. The theological meaning of Annanang Ase mantra is seen in the use of the phrase Anging battu ri makka/Nakarenaianging Battu ri Madinah 'wind coming from Mecca/mocked by the wind of Medina'. This mantra uses the sacred symbol of Mecca and Medina. The two cities are interpreted as a symbol of purity that can bring blessing. This phrase is interpreted as a hope that the rice grows well from something that is purified.

(4) Rice grain mantra (Rappo Ase)

Assalamu Alaikum Warahmatullahi Wabarakatu

Battungaseng mako mae sumangak asengku

I timboro - I wara

I raya - I lau

I rawa - I rate

Narurungang malaekak pakdoangnganna

Awalli passombalinna

Barakka Lailaha Illallah

Barakka Anna Muhammadarrasulullah

Assalama Alaikum Warahmatullahi Wabarakatu

'Come all the spirit of my paddy'

'in the South-in the North'

'in the East-in the West'

'above-below'

'the Angles' pray be with you' 


\author{
' the Wali be your Guardians' \\ Barakka Lailaha Ilallah \\ Barakka Anna Muhammadarrasulullah
}

The theological meaning of Rappo Ase mantra is seen in the closing sentence Barakka La Ilaha Illallah. The addressor recognition of the oneness of God becomes the life foundation of the owner society. In searching for sustenance we must have a clean heart and acknowledge that there is no God but Allah and Allah is the only substance that is worthy of worship and able to provide sustenance. The word Barakka is the hope of blessing and Lailaha Illallah is a recognition for the owner community. That is, there is a balance between the mundane and the afterlife. One sidethis mantra is a spiritual satisfaction. On the other side, this mantra is an attempt to work with vigor. Rappo Ase 'the rice contents' is defined as the symbolic sense of divinity, the sense of request that occurs because of circumstances. The situation forms a solemn and reverent atmosphere.

The theological meaning of Rappo Ase mantra is seen in the use of words angel and guardian, which is defined as the process of rice accompaniment. Both are believed to be the names of the guard of paddy so as not to be eaten by pests and that the contents of rice thrive. In other words, the uttering of angel and guardian names refers to the request for protection from something considered sacred. In addition, the lines I timborok - I warak 'in the South - North', I raya - I lauk 'in the East - in the West' show hablum minannas relationship between human beings who remain having good relationship. I rate - I rawa 'Above - Below' implies a religious meaning hablum minallah relationship between mantra reciter with Allah.

(5) Mantra of four directions (Appa Sulapa Nikutaknang)

Oh yaccingku nia aseng jako ilalang

Tenamo tumaboyanu

Iraya kalauko mae

Ilauka anraikko mae

Timboroka warakko mae

Warakka timborokko mae

I rateya naungko mae

I rawayya naikko mae

Kusalayya kusabbu

Kariolo mako battu

Naku panaimako anne yaccing

Ridulang-dulang pallunu

Ripallakka bulaengnu

Lao-lao pole

Tanairikmako anging

Tanararangko allo

Barakka Lailaha Illallah

Barakka Anna Muhammadarrasulullah

'O paddy, are you all there inside?'

'Is there anyone looking for you?'

'Those in the East please come to the West.'

'Those in the West please come to the East.'

'Those in the South, please come to the North'

'Those in the North, please come to the South'

'Those above, please come down'

Those below, please go up'

'The mistakes that I don't mention'

'For you come earlier'

'I will get you down paddy'

'on the trays where you will be cooked'

'On your golden berth'

'go and go again'

'You are not companied by wind'

'you are not shined by the sun either'

Barakka Lailaha Illallah

Barakka Anna Muhammadarrasulullah 
The theological meaning of Appa Sulapa Nikutanang is seen in the line Tenamo tumaboyanu 'is there anybody looking for you'. The sentence is an interrogative sentence which is implicitly asking that there is substance beyond the human self which can give blessings in life. Human life can be a blessing if there is a merger between the physical and the spiritual lives. Serenity and inner satisfaction are the key factor in the communities living with farming activities. The concept develops sincerity of the owner society. This is seen in the line Lao-lao pole 'goand go again'. Literally it is interpreted that the rice is grown and harvested and planted again and again. The meaning implies that in every life, something comes and goes. Like a cycle that always spins following the time. The understanding adds the inner strength for the addressor and addressee.

Based on the analysis, the theological meaning of the Tulembang mantra is dominated by indexical signs that imply a belief in God as the Single Ruler. To God men plead and pray. The mantra also indicates more symbols of the meaning creation that raise the notions of strength and recognition of the divinity. This mantra shows a knowledge of divinity and the basic belief in God based on the holy book of the Koran.

Theological meaning of Appa Sulapa Nikutanang is seen in the mention of the phrase oh Yaccingku nia ngaseng jako ilalang/Tenamo tumaboyanu 'O paddy are you all there inside?'/'Is there anyone looking for you?' is an attempt to convey the meaning that the content of grain is fully charged. This is done by giving a greeting to the rice about to be harvested the next day. The mention of the phrase Is there anyone looking for you?' is an attempt to call the rice so that the contents remain in the grain.

The mention of the phrase Iraya kalauko mae/Ilauka angraikko mae/Timboraka warakko mae/warakka timborokko mae/Irateya naungko mae/Irawayya naikko mae 'East please come to the west/Western please come to the East/South please come to the North/North and please come to the South/below please rise to the top/above please get down to the bottom 'is an attempt to bring in the hope that the content of rice can be contained, despite being located in the area of rice fields. The phrase also refers to the condition of paddy and ground elements. Rice contents (above) can be lowered to the ground. Thus the results that rice can be harvested and become the result of fertile land. The words I rawa - I rate 'from below to the top' refer to the treatment and fertilizing so that the fertilized soil can bring maximum yields. The mention of Nakupanaungko anne yaccing 'I bring you down paddy' is the submission of a request for permission in order that the coming harvest can run smoothly. The mention of Ridulang-dulang pallunnu/ri pallakka bulaeng 'on your cooking trays', 'on your golden berth' is a request that the rice can contain so that the crop can be stored in its berth ripammakang/pallakka farmhouse ceiling or granary. The uttering of Lao-lao pole/tanairikmako anging/tanararang mako allo 'go-go again/you is not accompanied by the wind/You really are not exposed to the sun 'refers to the condition of rice stored in barns that are no longer in contact with the wind and the sun, as if resting. It is expected that the harvest of rice are filled and can be stored on the pallakka/barn. Rice is placed on top or in the upper house because rice is considered as the source of life of the traditional farmer Makassar people.

\subsection{The meaning of Tupakbiring mantra text}

The text of Tupakbiring mantra has theological meaning like the Tulembang mantra. For traditional fishing community of Makassar ethnic, God becomes the foundation to carry out daily activities. Each activity can not be separated from the divinity within the owner community. This is because the activities undertaken need physical and mental strength. An understanding of divinity can provide a strong foundation for the truth about Islam or religious faiths of the community.

(6) Mantra for Avoid Danger (Songka Bala)

Eh Imanrembassang

Dongkokanna nabbi Nuhung

Eh Imanrembassang

Assengngak na kuassengtongko

Cinikka na kuciniktongko

Jangjangak na kujangjang tongko

Katutuiya naku katutui tongko

Ngaiya na kungai tongko

Na nuboyanga dallekku

Na nusongka sikamma bala nantattabayya

Inakke sibatu biseang

Napunna tanu pakamma kanangku

Kapallakko ri Muhammad Rasullullah

Kainakke minne Muhammad

Eh Imanrembassang

'The boat used by the Prophet Noah' 


\section{Eh Imanrembassang}

'Know me so I can know you too'

'Look at me so I can see you too'

'Behold me so I can behold you too'

'Love me so I can love you too'

'Be fond of me so I can like you too'

'And find me sustenance'

'And protect me from all dangers to come'

'Myself and all parts of my boat'

'If you don't listen to my words'

'You ignore Muhammad Rasullullah'

'And I am Muhammad'

The theological meaning of Songka Balais seen in the use of Kainakke minne Muhammad 'and I am Muhammad'. This line is a type of contradiction and paradox. This line is a statement that is contrary to the speakers. In other words, this is not a sentence indicating the speaker, i.e. Prophet Muhammad, but it emphasizes that through the Prophet Muhammad, the distress or danger will stay away.

The theological meaning of this mantra is apparent in the use of metonymy of the Prophet Muhammad. This sentence shows the belief as a form of relationship between man and God through the Prophet Muhammad. Prophet Muhammad is considered as a transmitter of faith about the existence of Most Perfect Allah, Omnipotent and has other properties of perfection. This is supported by reinforcements of word bala 'danger'. This word implies that everything in life has evil spirits, and so an approach to God is needed to be protected from harm.

The theological meaning of Songka Bala mantrais seen in the use of the phrase Nanu songka sikamma bala nantattabayya 'and protect us from all impending danger'. Religiosly, the mantra text is interpreted as protector from danger. This is reinforced by the mention of Imanrembassang as a symbol of Noah's boat. It means that the danger will not be able to rock the boat like Noah's boat. The traditional fishing communities of Makassar ethnic believe through Imanrembassang to be saved from dangers threatening at any time when at sea. Moreover, flying fish Isarangki will come, that is female flying fish and Itajijintu, the male fish to have sexual intercourse and lay eggs in the fish trap of the mantra users to take home.

The Noah name mentioned above is expected to provide protection to avoid big waves in the sea. In the name of Noah, it is expected to help the fishermen who use mantras to avoid the local winds, for example Irala (strong winds coming at night), Laso Anging (hurricane or tornado), Imuharrang (wind which attract each other sometimes appear to have eyes like human).

(7) Mantra of sail ropes (Loloanna Sombalakku)

Tepokpi anne terak-terasakku

Natepok todong lekok gulingku

Polongpi bonggangku

Napolong todong bongga gulingku

Tepokpi paling-palingku

Natepok todong baukku

Tappukpi nyawaku

Natappu todong loloanna sombalakku

'Later my shinbone may be broken'

'my steering wheel just broke'

'Later my thigh fracture'

'my steering rod jus broke'

'later my arms broke'

My masts just fracture'

'my life then ends'

'my sail ropes broke too'

The theological meaning of Loloanaa Sombalakku mantra is seen in use of the word nyawaku 'my life'. This word implies that everything in this life will die. There is a recognition that there is a substance in power beyond their capabilities. As traditional fishing community of Makassar, it is important to keep away from things that can not be predicted when fishing. Therefore, the theological meaning of this mantra is a safety relief request by using metony my with physical presupposes of the human body and the boat as a whole that 
can not be separated. The fishermen ask God to be given health and safety in the search for sustenance in the sea. This is interpreted as a manifestation of God's creation and those are created to be united that add strength and confidence.

The theological meaning of Loloanaa Sombalakku mantra is noted in the use of the word, Tappapupi nyawaku na tappauk todong lolonna sombalakku 'when I die later the rope of my sail will also broke'. It indicates that all of God's creation will be destroyed when the time comes. In addition, the word 'boat' is a symbol interpreted as blessing bearer, spirit, and safety. The meaning is evident from the way it treats the boat. The sawi chooses light color paint, for example, a combination of blue with white, below part of the boats are painted in blue and white at the top. They paint the boat in order to look brighter and give rise to a new spirit.

In addition, the sawi fill the boat with various fly fishing gear, offerings (papparappo), rice, coffee, sugar, and fresh water. Sorongang contains onion, garlic, laksa, ginger, nutmeg, cinnamon, kalomping and gambier. Those sorongang contents are useful as drugs as they would go to sea for days. Special papparappo contains betel leaf (lekok), betel nut (rappo), chicken eggs, and red candles (tai bani). Traditional fishermen of Makassar ethnic will stop on the island of Sanro Bengi to lower the offerings, placed on the waves up and down near the island.

(8) Mantra of seaweed (Gosse)

Assalamu Alaikum

Ikau gosse Irapang jintu arengnu

Ri Allah Taalah

Nabbi Pahara nabbinu

Inakke iyukkung arengku

Ri Allah Taalah

Nabbi Muhammad nabbiku

Nabattu ulunnajako

Antu Nabbi Adam ajjari batu

Nalabbi Uk pammantangang najako

Antu nabbi Hawa ajjari gosse

Naalleko Ali

Napabarakkako Nabbi Muhammad

Assalamu Alaikum

'You, seaweed is your name'

'from Allah Taalah'

'The prophet keeping the seaweed is your prophet'

'my name is yukkung'

'from Allah Taalah'

'Prophet Muhammad is my prophet'

'you came from His head'

'The prophet Adam turned into a stone'

'Just over her hair alone'

'Prophet Eve became the seaweed'

'you are taken by Ali'

'blessed by prophet Muhammad'

Gosse mantra uses the words gosse 'seaweed', Assalama Alaikum for the opening, the words Ri Allah Taalah and Napabarakkako Nabbi Muhammad 'Prophet Muhammad is my Prophet'. Those words become theological indexical meaning to get or to obtain something wished because of God. The wish is an index to the belief in the power possessed by Allah and the safaat of Nabi Muhammad SAW. Assalama Alaikum as nonsense that carries the notion a request for safety from Allah the Owner of the universe. The above mantra represents understanding of construction of religious 'thoughts'. The request for safety and good sustenance is not directly addressed to Allah, but by mentioning the mediator earlier. The mentioned mediator is Muhammad SAW.

The theological meaning of Gosse mantra is seen in the use of the name of a prophet, such as the use of the word Nabattu ulungnajako Nabbi Adam akjari batu 'Adam became a rock ', Nalabbi Uk pammangtanganna jako/Nabbi Hawa akjari gosse 'Just over her hair alone' 'Prophet Eve became the seaweed'. This refers to the seaweed, which generally grows well in coastal reefs, because it is in this area that the seaweed could grow well. The use of the sentence 'you are taken by Ali' refers to the strength of 
request by uttering holy name, i.e. a friend of the Prophet Muhammad. Ali, the companion of the Prophet becomes an amplifier strengthening the boat and the sound of vowel A-I-U that are usually used during activities among Makassar community, especially the traditional fishermen by checking the breath coming out of their noses. If the breath comes out through left nostril, it means that they have to be patient to wait until the breath comes out of the right nostril signaling they can start activities.

(9) Mantra of preserving fish (Bunoanna Jukuka)

Assalamu Alaikum

Iyakking jintu areng tojeng-tojengmu

Ri Allah Taallah nuing karaengnu

Nabbi Sulaimana nabbinu

Inakke iyukkung ampatinroko

Nuttinromo naung rikatoang majannannu

Rikasorok malannyinnu

Ritapperek matangkasaknu

Nukamma todong tinrona bunting berua

Lebbak junnuko - lebbak satinjaiko

Nuttambung nukbumbung

Kamma todong pattambunnu Lompobattang

Nukbumbung kamma todong pabbumbunnu Bobokareang

Assalamu Alaikum

Iyakking is your true name'

'From Allah Taalah becomes your God'

'Prophet Solomon is your prophet'

'I am iyukkung that makes you sleep'

'Just sleep in your tray of serenity'

'In your soft mattress'

'In your clean mats'

'Just like a new bride sleep'

'After junub bath - and was clean'

'Stacked and mounting'

'Just like Lompobattang piled mount'

Mounting just like mount Bawakaraeang that mounts you'

The theological meaning of Bunoanna Jukuka mantra is the same as Gosse mantra, which is seen in the use of the phrase Ri Allah Taalah. This word implies recognition that sustenance comes from Allah Taalah. The recognition is made clear by the phrase Inakke iyukkung ampatinroko 'I am iyukkung who make you sleep'. This means that the sentence acknowledges that he belongs to God and everything that happens to humans is the will of God. Humans are only guardians of nature in order to remain sustainable and well preserved. It is just like natural products such as the new bride who always honor and keep each other happy. This would foster inner satisfaction for the addressor and addressee.

Theological meaning of Bunoanna Jukuka mantra is the same with Gosse mantra that is visible from the use of the name of the Prophet. The use of the name of Prophet Solomon is interpreted as a symbol of triumph and blessing. In addition, it is due to the ability of Solomon in the language of animals. Hopefully, through this sentence the message of mantra will arrive just as the Prophet Solomon who is able to communicate well with all animals.

(10) Mantra of removing the evil (Appasuluki Kodia)

Bismillahirrahmanirrahim

Kuniakkanngi Abubakara - Umara - Usman - Ali

Ammenteng risulapak

Appakna biseangku

Anjagai panraka

Ampantamaki bajika

Appasuluki kodia

Pattantanna Rasulullah

Punna nia tausalah atekakna anlaloi

Taenami tallasakna nakana Allah Taalah 
Ruhu Ilapi anmmenteng ripoccina biseangku

Anjagai panraka

Ampamtamai bajika

Appasuluki kodia

Punna nia tausalah atekakna angkira-kirai biseangku

Labboro kamma tongi ceklayya

Nasabak Allah Taalah

Barakkah Lailaha Illallah

Barakkah Anna Muhammadarrasulullah

Bismillahhirohmanirrahim

'On behalf of Allah, Most Gracious, Most Merciful'

'I want Abubakar - Umar - Usman - Ali'

'stand up in four important parts'

'In my boat'

'To keep the damaged'

'incorporate the good'

'kick out the evil'

'The protector is Rasulullah'

'If there is one who passes his intentions'

'He has lost his life according to Allah Taalah'

'Divine Spirit stands in the center of my boat'

'to keep the damaged'

'incorporate the good'

'kick out the evil'

'If there were any intentions aiming boat'

'Melting like salt in water'

'because Allah Taalah'

Barakkah Lailaha Illallah

Barakkah Anna Muhammadarrasulullah

The theological meaning of Appasuluki Kodia mantra appears from the use of Bismillahirrahmanirrahim and Ruhu Ilahi anmmenteng ripoccina biseangku 'Divine Spirit stands in the center of my boat'. This phrase carries the notion of recognition that Allah is always with the human beings, keep out and drive away the evils. The word Bismillahirrahmanirrahim becomes the foundation of belief in Allah. This is in line with the Koran, that almost all the readings of the Quran are preceded by Bismillahirrahmanirrahim sentence. The symbol of Bismillahirrahmanirrahim implies hopes and wishes of the mantra reciter to gain safety and sustenance from Allah as the Supreme.

The theological meaning of Appasuluki Kodia mantra implies protection from danger or request to be kept away from any sort of damage, evil, and destruction. The use of Kuniakkangi Abubakar-Umara-UsmanAli/angmenteng risulappak/Appana biseangku 'Iwant Abubakar-Umar-Usman and Ali/stand up in four important parts/in my boat' aims to be saved from misfortune that falls on the boat and the crew. The sentence Ruh ilapi ammenteng ripoccina biseangku 'Ruh Ilahi stands in the center of my boat' has a wide meaning including request for protection during sailing to be kept away from any forms of evil and damage including diseases. Appa suluki kodia, means taking out all bad things on the boat and expect for all goods coming into the boat to smoothen the finding of flying fish at sea.

\section{Conclusion}

The meaning of Tulembang mantra and Tupakbiring mantra are analyzed through theological elements. The theological meaning of Tulembang mantra is that Allah becomes the foundation for the belief of traditional farming society of Makassar ethnic in order to expect the blessing of sustenance. In other words, theologically, Tulembang mantra implies: recognition, hope, hygiene (sanctity) self and heart, serenity; and spiritual satisfaction. Mantra Tupakbiring, theologically has no recognition meaning that rival the power of Allah Taalah, strengthening the mind, the approach to God in order to be protected from harm, and contains teachings to do good and leave the vile and evil. In addition, the mantras of Tulembang and Tupakbiring are embodiments of belief in the existence of a cosmic force that controls the universe. 


\section{Acknowledgement}

The successful completion of The Meaning of Tulembang and Tupakbiring Mantras in the life of Makassar Ethnic is the result of the cooperation, confidence, and endurance of many people. The Writer greatly appreciates the contributions of the individuals listed below. Professor I Wayan Cika, Profesor Tadjuddin Maknun, and Professor I Nyoman Suarka have consistently encouraged me to finish my writing. They all my promoters when I studied for my doctorate program in Udayana University, Indonesia. I also want to express special thanks to my colleagues who commented the drafts of the writing and provided some advices and support: Ader Laipe, Novena Sujiwo, Alwi Rachman, Abdul Madjid, Ayub Khan and Professor Nujihad Saleh. Finally, for support beyond anything I can describe, I thanks all the members of my family, especially my wife Iriani, and three children Sastryani, Siddiq, and Syahdan to whom this writing is dedicated.

\section{References}

[1] Culler, Jonathan. 1981. The Pursuit of Signs. Semiotics, Literature Deconstruction. London: Routledge and Kegan Paul.

[2] Maknun, Tadjuddin. 2006. Perilaku Verbal dan Nonverbal Nelayan Patorani di Galesong Kabupaten Takalar, Sulawesi Selatan, Lensa Budaya: Jurnal Ilmu-ilmu Budaya, Vol 1 No 1, Desember. Unhas Makassar.

[3] Moleong, Lexy. J. 2005. Metodologi Penelitian Kualitatif.Bandung: PT Remaja Rosdakarya.

[4] Preminger, Alex, dkk. 1974. Princeton Encyclopedia of Poetry and Poetics. Princeton University Pres: Princeton.

[5] Ratna, Nyoman Khuta. 2006. Teori, Metode, dan Teknik Penelitian Sastra, Yogyakarta: Pustaka Pelajar.

[6] Riffaterre, M. 1978. Semiotics of Poetry. Bloomington: Indiana University Press.

[7] Semi, Atar. 1993. Metode Penelitian Sastra. Bandung: Angkasa.

\section{Author biography}

M. Syafri Badaruddin was born in Makassar, 6 November 1953. He wrote some articles in several differnt journals: 1. Form Academic Journal, Vol 1 no 1, April 2000, Black Experience under the Domination of Bourgois, White Society as Seen In Tony Morrison's Sula, Makassar, Faculty of Letter Hasanuddin University. 2. Percikan Journal vol 31 May 2001, Western Formula As Seen in Zane Gray's The Mysterious Rider, Bandung, Percikan KKJ. 3. Educational and Humanity Journal, vol 2 no 2, Agust 2004. The Role of Women as Reflected on Ulrich's Good Wives and Sorkarno's Sarinah, Pare-Pare, Muhammadiyah. 4. Journal of Culture, English Language Teaching \& Literature vol. 6, Semarang, December 2006. An Expose of Macho Characters in Louis L'Amour's Western Novels: Brionne, The Californios, and Hondo. Semarang, University Press. 5. Hasanuddin University Research sponsored by Dikti JKT, 2007. Cultural Value in Makassarese Folklore, Hasanuddin University Research. 6. Malaysia-Indonesia: Serumpun Merentasi Globalisasi,2014. Pembauran Budaya Indonesia-Malaysia Dalam Novel Cakra Waruga Karya Arena Wati, Kuala Lumpur, Universiti Malaya. 7. e-journal of Linguistics vol. 10. NA. 1-6 ISSN: 2442-7586. January 2016. The Structure of Tulembang and Tupakbiring Mantras in the Life of Makassar Ethnic, Linguistic Program Postgraduate, Udayana University, Bali.

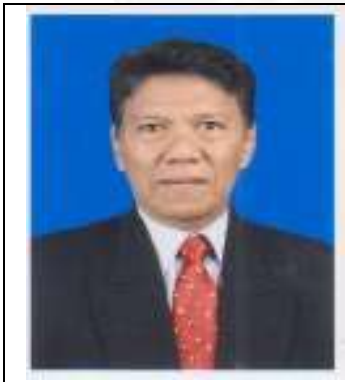

Dr. M. Syafri Badaruddin, M.Hum is full-time lecturer of the Faculty of Culture and Social Sciences, Hasanuddin University, Makassar, Indonesia. He graduated his Master of Humanity in Gadjah Mada University, Yogyakarta. Then, he graduated his doctorate in Udayana University, Bali. In 1984-1985, he completed a course of instruction in General and Applied Linguistics, Reading University, England. In 1988, he has successfully completed the course of Language Syllabuses and Language Teaching, SEAMEO Regional Centre, Singapore. In 1989-1990, he participated successfully in International Educational Exchange Program between Canada and Indonesia, British Colombia, Vancouver Canada. In 1992 attended short course in Training of Trainers In EAP Course Management and EAP Curriculum Development, Leeds University, England. In 2012, he attended sandwich program in Leiden University, Leiden, and Netherland. 